S. Elen, PhD, Senior Research Scientists Geological Institute Slovak Academy of Sciences 1, Dumbierska Str., Banska Bystrica, 97401, Slovakia E-mail: jelen@savbb.sk

L. Skakun, PhD, Associate Prof. Ivan Franko National University of Lviv 4, Hrushevskyi Str., L'viv, 79005, Ukraine E-mail: Izskakun@gmail.com

O. Grinchenko, PhD, Associate Prof. Taras Shevchenko National University of Kyiv 90, Vasylkivska Str., Kyiv, 03022, Ukraine E-mail: alexgrin@univ.kiev.ua

S. Bondarenko, PhD, Senior Research Scientist Institute of Geochemistry, Mineralogy and Ore Rormation NAS of Ukraine

34, Acad. Palladina Ave., Kyiv - 142, 03680, Ukraine E-mail: sbond@igmof.gov.ua

T. Mikus, PhD, Research Scientist Geological Institute, Slovak Academy of Sciences 1, Dumbierska Str., Banska Bystrica, 97401, Slovakia E-mail: mikus@savbb.sk

T. Ztevkova, PhD, Research Scientist Faculty of Natural Sciences Comenius University B-1, Mlynska Dolina Str., Bratislava, 84215, Slovakia E-mail: timea.stevkova@apvv.sk

T. Mironchuk, PhD, Associate Prof. Taras Shevchenko National University of Kyiv 90, Vasylkivska Str., Kyiv, 03022, Ukraine E-mail: tatianakiev99@gmail.com

\title{
BISMUTH MINERALIZATION IN NEOGENE VOLCANITES OF UKRAINIAN CARPATHIANS AND SLOVAKIA
}

(Рекомендовано членом редакційної колегії доктором геол. наук, доц. С.Є. Шнюковим)

The paper discusses distributional features of bismuth mineralization in the Neogene volcanites covering Ukraine and Slovakia. Bismuth is a typical element of many gold, polymetallic, and copper-porphyry Neogene deposits of the Ukrainian trans-Carpathians and Slovakia. Due to its intrinsic minerability, bismuth produces sundry minerals that are sensitive to certain physical and chemical environment. Therefore, studying bismuth features reveals principles of ore formation. Despite the fact that bismuth minerals mostly form submicroscopic aggregates, they can be indicators of the physical and chemical environment essential to form ore systems, for their composition is highly sensitive to minor variations in such parameters as temperature, Eh-pH, $f \mathrm{Te}_{2}, f \mathrm{~S}_{2}, \mathrm{fSe}_{2}, \mathrm{fO}_{2}$, and others.

Both within the trans-Carpathian region of Ukraine and on the territory of Slovakia there are distinctly traced two stages of bismuth mineralization, both being synchronous with volcanic eruptions of the Miocene and Pliocene ages, accordingly. Each stage of volcanic ejection reveals a certain typo-morph of bismuth minerals and a different degree of bismuth mineralization manifestation. It has been established that bismuth sulphosalts are the products of the Miocene volcanites and the associated epithermal deposits, while manifestations of bismuth-tellurium mineralization are widespread in the metasomatically altered volcanites of the Pliocene age.

Miocene epithermal deposits are characterized by native gold-Bi-sulphosalts-bismutite-chalcopyrite-quartz paragenesis formed from neutral solutions persisting adularia due to the replacement of the earlier formed sulphides, mostly galenite. This stage shows the reduction of $\mathrm{Ag} / \mathrm{Cu}$ ratio in time. Minerals going through a number of phases during mineralization is put down to the fact that most of them form metastable and intermediate links during metasomatic replacements caused by spatial and time variations in hydrothermal solutions.

Bismuth-tellurium-selenic mineralization is distributed in the metasomatically altered Pliocene volcanites of the Vyhorlat-Ghuta ridge. Bismuth-tellurium ore manifestations are associated with high-temperature pneumatolytic-hydrothermal systems, with acid solutions being predominant, which is proved by a wide distribution of kaolinite-hydromica metasomatites. Broad distribution of Bi-Te-Se mineralization in the Pliocene volcanites of the Vyhorlat-Ghuta ridge provides evidence to considering this structure a unique metallogenic province on the European continent.

Key words: bismuth, mineralization, Ukraine, Slovakia.

Introduction. Bismuth is a typical element in many gold, polymetallic and copper-porhyry Neogene deposits of the Ukrainian trans-Carpathians and Slovakia. The behavior of bismuth in gold mineralization process is similar to the behaviour of gold itself, that's why when mineralogical and geochemical investigations are carried special attention is commonly paid to this element. Gold, silver, bismuth and tellurium prove to be genetically related due to their spatial affinity and common features of crystallisation during hydrothermal process [2]. Similarly, bismuth minerals are indicative of gold-bearing paragenesises, and are found in, virtually, all gold-bearing deposits discovered on the territory of the Ukrainian trans-Carpathians and Slovakia $[8 ; 11]$. Due to its inherent mineralization, bismuth forms sundry mineral varieties sensitive to certain physical and chemical conditions in different mineralogical environment. Therefore, a comparative study of bismuth behaviour in ore-bearing neovolcanites of both Ukrainian and Slovakian provinces is vital in understanding the processes and features of gold mineralization.
Despite the fact that in most cases bismuth minerals form submicroscopic segregations, they can serve as indicators of physical and chemical conditions of ore formation because their composition is highly sensitive to slight variations in temperature, Eh-pH, $\mathrm{fTe}_{2}, \mathrm{fS}_{2}, \mathrm{fSe}_{2}, \mathrm{fO}_{2}$, and some other parameters.

Background. Based on the findings of the research carried and the data on the regional features of the distribution, mineralogical and geochemical properties of bismuth mineralization out of the Neogene volcanites in the Ukrainian Carpathians and Slovakia, there were established some typical features of bismuth distribution and mineralogical forms of their occurrences. Basically, regionalgeochemical bismuthic mineralization is characterized by a marked contrast in the distribution of bismuth - from its dissemination in sedimentary and volcanic rocks to high and sometimes "tremendously high" concentrations of bismuth regularly revealed in the products of metasomatic alteration of the Neogene volcanites. There can be distin- 
guished two stages of bismuth mineralization within the trans-Carpathian region of Ukraine and the territory of Slovakia, both being synchronous with volcanic processes of the Miocene and Pliocene ages, correspondingly. The volcanic eruptions, in turn, can be connected with the subduction of European Plate under Carpathian volcanic arch or regional displacement of Panonian terraine [9]. Numerous volcanic ejections of the Miocene age are spatially confined to the internal zone of the inner-Carpathian volcanic belt (Berehivske, Preshov, Middle-Slovakian structures), while volcanic formations of the Pliocene age are mainly locallized within the external zone of this belt. They form a regional structure, the Vyhorlat-Ghuta ridge, which stretches both on the territory of Ukraine and Slovakia [6].

Each stage of volcanic activity is characterised by a certain typomorphic set of bismuth minerals and a different degree of the bismuth mineralization manifestation. It was established that such mineral varieties as bismuth sulphosalts are characteristic of the Miocene volcanic formations, epithermal and mesothermal gold, and polymetalic deposits associated with them. Meanwhile, the manifestations of bismuth-tellurium mineralization are mostly spread in the metasomatically altered volcanic varieties of the Pliocene age that are localised within the Vyhorlat-Ghuta ridge.

In Miocene volcanites bismuth mineralization is mainly revealed in correlation with gold in polymetallic ores of the Neogene volcanites within the Berehivske and Central-Slovakian ore fields (Banska Shtiavnitsa-Hodrusha). Mostly, gold-polymetallic deposits and ore manifestations of the Ukrainian trans-Carpathians - Muzhyivske, Berehivske, Behanske, Kuklianske deposits and Bucha, Kvasove ore manifestations - are localised within the Berehivske ore field. The location of the ore bodies is outlined by the structures closely associated with calderas, crater necks, and extrusion formations. Ore bodies occur in apical and near-contact zones of subvolcanic intrusives, fracture zones, radial and arc faults of calderas, dome raisings, linear zones of faults, stocks and veins of explosive breccias. Ore-bearing rocks are represented by metasomatically altered rhyodacitic tuffs and explosive breccias, uncommonly by porphyrites and basic porphyritic tuffs, as well as by subvolcanic intrusions.

The conditions might relate the deposit formation to the near-surficial, low-to-middle temperature environment, which corresponds, according to standard international classification, to the formations of epithermal-copper-porphyry type. Within the Muzhyivske deposit of the Ukrainian trans-Carpathians (the one being most thoroughly investigated), the manifestations of gold-polymetallic and gold-quartz-sulphide mineralization are localised mainly in the plagioliparites and plagioliparite-dacite formations of the middle tuff horizon of the lower level; whereas the manifestations of pure gold and goldsilver mineralization are confined to the explosive breccias that were subjected to intensive argyllisation in the upper horizons of ore structures.

The paragenesis of bismuth minerals with Sb-Assulphosalts, chalcopyrte, native gold, quartz and adularia is characteristic of the Sarmatian gold-polymetallic deposits in the Berehivske (the Berehivske deposit) and Central Slovakian (the Banska Shtiavnitsa and Hodrusha deposits) ore fields. In the Berehivske ore field the area of the paragenesis mentioned above is characterised by distinct mineralogical-geochemical zonality, in which antimony minerals (bournonite, tetrahedrite) occupy peripheral position on the flanks and upper part of the ore columns (mainly in the Muzhyivske deposit), whereas bismuth mineralization (BiAs gray ores, galenite-matildite solid solutions, $\mathrm{Cu}-\mathrm{Bi}-\mathrm{Pb}$ sulphosalts, bismutite) occurs at the lower horizons of the central, chalcopyrite-rich narrow zones (only in the Bere- hivske deposit) [1]. There was identified an increase of the bismuth sulphosalt content being in direct ratio to the hypogene concentrations of chalcopyrite in the veins of the Banska Shtiavnitsa-Hodrusha ore field [3].

The investigation having been carried out, there were revealed some common features in the evolution of the $\mathrm{Cu}$ $\mathrm{Bi}-\mathrm{Pb}$ sulphosalt composition in the Berehivske and the Banska Shtiavnitsa-Hodrusha ore fields. In the Beregove deposit Bi-sulfosalts occur as the inclusions in galenite grains found in fine-grained quartz and adularia-quartz aggregates [2]. The same genesis is observed in the ores of the Banska Shtiavnitsa-Hodrusha deposits [5]. This association is of reactive, metasomatic nature, which is proved by a wide distribution of symplektites in the contact zone between sulphosalts and galenite and between chemically-heterogeneous sulphosalts.

All bismuth sulphosalts can be classified into four groups:

1. the Ag-Bi-Pb sulphosalts represented by matildite$\mathrm{AgBi}_{2}$-galenite solid solutions in both ore fields, with the persistence of galenite-lillianite $\left(\mathrm{Pb}_{2} \mathrm{Bi}_{2} \mathrm{~S}_{6}\right)$ modular structure type, mostly being minerals of ourayite series $\left(\mathrm{Ag}_{4} \mathrm{PbBi}_{6} \mathrm{~S}_{12}-\mathrm{Pb}_{11} \mathrm{Bi}_{2} \mathrm{~S}_{14}\right)$. The veins of the Berehivske deposit show the presence of gustavite-lillianite and treasurite $\mathrm{Ag}_{7} \mathrm{~Pb}_{6} \mathrm{Bi}_{15} \mathrm{~S}_{32}$ sulphosalts. Mineral phases of this group are mostly represented by myrmekite and lamella-like structures of galenite replacement.

2. the $\mathrm{Cu}-\mathrm{Ag}-\mathrm{Pb}-\mathrm{Bi}$ sulphosalts, similar in composition to benjaminite $(\mathrm{Ag}, \mathrm{Cu})_{3}(\mathrm{Bi}, \mathrm{Pb})_{7} \mathrm{~S}_{12}$, and berryite $\mathrm{Pb}_{3}(\mathrm{Ag}, \mathrm{Cu})_{5} \mathrm{Bi}_{7} \mathrm{~S}_{16}$, including a number of $\mathrm{Ag}_{5} \mathrm{CuBi}_{4} \mathrm{~Pb}_{11}$ $\mathrm{AgCu}_{5} \mathrm{Bi}_{4} \mathrm{~Pb}_{2} \mathrm{~S}_{11}$ phases and characteristic of the Banska Shtiavnitsa-Hodrusha ore field. They form thin intergrowths with $\mathrm{Ag}-\mathrm{Pb}-\mathrm{Bi}$ sulphosalts and chalcopyrite in galenite.

3. the $\mathrm{Cu}-\mathrm{Pb}-\mathrm{Bi}$ sulphosalts represented by the intermediary aikinite $\mathrm{CuPbBi}$-bismuthite $\mathrm{Bi}_{2} \mathrm{~S}_{3}$ series. They are widespread in the aggregates of the Banska ShtiavnitsaHodrusha deposits [4] in the form of intergrowths with Ag$\mathrm{Pb}-\mathrm{Bi}$ sulphosalts, chalcopyrite and bismutite. As single grains, they are found in the Berehivske deposit ores [2].

4. the $\mathrm{Cu}-\mathrm{Bi}$ sulphosalts, homologues of cuprobismutite (hodrusite, kupcikite), found only in the Hodrusha deposit ores as predominant phases among the bismuth sulphosalts in the hematite-chalcopyrite-quartz ores.

Ore aggregates of the Berehove, Shtiavnitsa and Hodrusha deposits reveal common features in the evolutionary composition of bismuth sulphosalts. The main variations in bismuth sulphosalts composition are described by two factors - variations between $\mathrm{Pb} / \mathrm{Bi}$ and $\mathrm{Ag} / \mathrm{Cu}$ ratios to galenite depletion (the latter being initially an unstable phase), and an increase in the amount of chalcopyrite in the chemistry of quartz aggregates. The occurrence of bismuth mineralization is marked by the formation of myrmekite and lamella-like structures that replace galenite. At this stage there are formed $\mathrm{Ag}-\mathrm{Bi}-\mathrm{Pb}$ sulphosalts. An increase of $\mathrm{Bi}$ and $\mathrm{Cu}$ activity in solutions results subsequently in the formation of $\mathrm{Cu}-\mathrm{Bi}-\mathrm{Pb}$ sulphosalts and their gradual replacement by $\mathrm{Cu}-\mathrm{Pb}-\mathrm{Bi}-\mathrm{Cu}-\mathrm{Bi}$-varieties. The stages of bismuth sulphosalts formation are shown on Fig. 1 by arrows. The sulphosalts described should be considered as metastable, intermediate phases of galenite replacement by chalcopyrite against the temporal increase in $\mathrm{Bi}$ and decrease in $\mathrm{Ag}$ activities. The final stage of this process is manifested by the formation of quartzchalcopyrite-bismuthite aggregate. The differences revealed can be explained by the fact that the processes mentioned above occurred more intensively within the Banska Shtiavnitsa-Hodrusha ore field, which finally resulted in the persistence of the most stable phases, the reduction in compositional variations, and a wide distribution of cuprobismutite homollogues. 


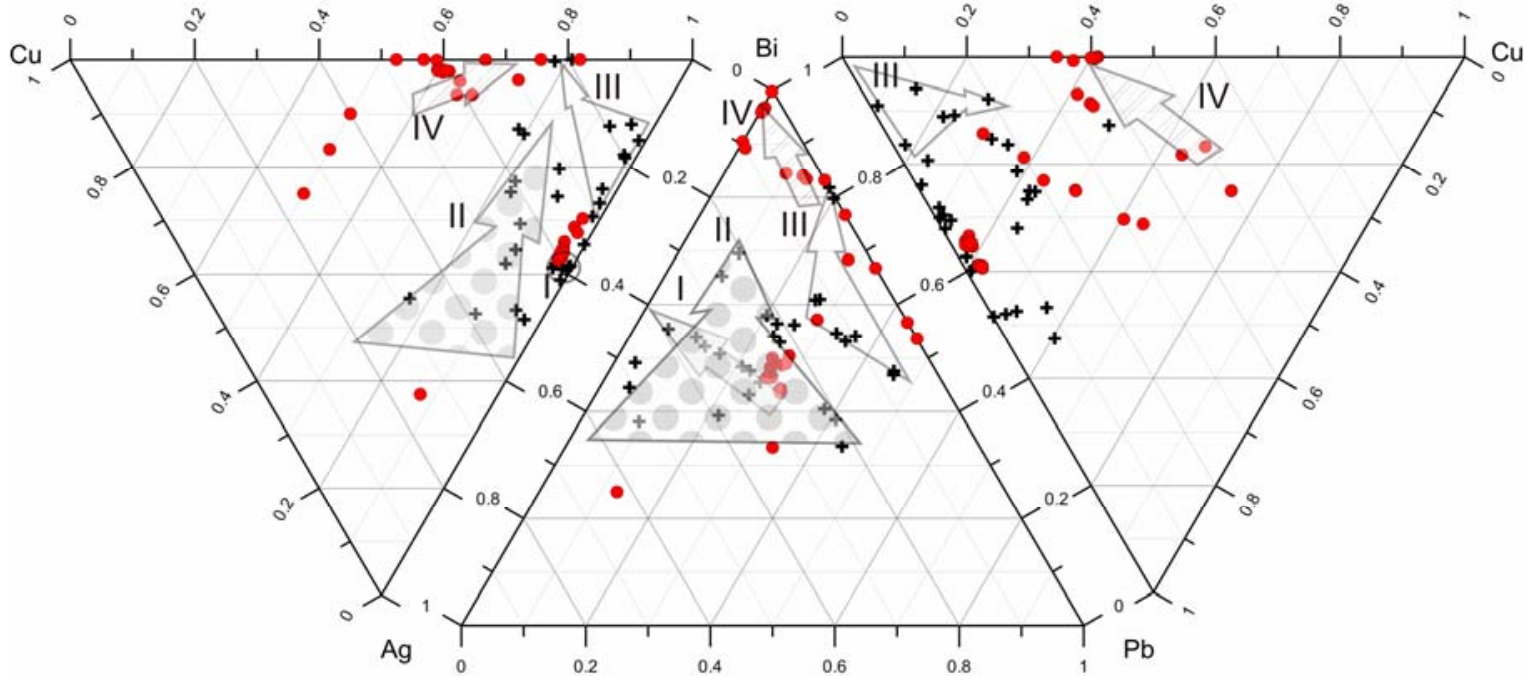

Fig. 1. Variations in $\mathrm{Cu}-\mathrm{Ag}-\mathrm{Pb}-\mathrm{Bi}$-sulphosalt composition in the Berehivske (crosses)

and Banska Shtiavnitsa (circles)ore fields. Arrows show time variations in the composition of various sulphosalts: I - Ag-Bi-Pb; II - Ag-Pb-Bi; III - Cu-Pb-Bi; IV - Cu-Bi

Bismutite proper was revealed only in the massive aggregates of chalcopyrite (Beregove, Hodrusha-Gamre). Gold was noticed to associate with chalcopyrite. Thus, slight gold-bismutite-tetradymite paragenesis was found in epithermal gold deposits of Slovakia (Banska Shtiavnitsa, Hodrusha, Zhupkov) [10; 11].

Bismuth mineralization of the metasomatically altered Neogene volcanites is identified by the development of Bi-Te-Se-S paragenesises within the Vyhorlat-Ghuta ridge [8]. Genetically, volcanogenic rocks of the Vyhorlat-Ghuta ridge are related to the basalt-andesite-rhyolite formation, which hypabyssalsubvolcanic component is represented by gabbro-diorite monzodiorite-granodiorite series that are characterized by central depression - calderas surrounded by arcs of volcanic structures and associated polygenic dome-ring structures [6].

Epithermal manifestations of $\mathrm{Bi}$-Te mineralization are confined to the Late Pannonian-Levantine volcanic ring structures localized on the territory of Ukraine and Slovakia (Table. 1). Concentric ore-geochemical zonality found in these structures testifies to genetic relation between their mineralization and evolution. They are localized in the focal part of the dome-ring structures: the pre-neck volcanic zones. Metasomatites are mainly confined to the axial area of the ridge where fumarole-solfataric activity occurred intensively. The fields of hydrothermal-metasomatic alteration with disseminated bismuth-tellurium mineralization are localized in the overlying intrusive part of the geological section. The altered rocks are represented (according to their topdown replacement) by argillizite-beresite-propylite facial series, with the occurrence of deep-laying turmaline-beresitegreisen associations in the monzodiorite-porphyries. Sometimes the content of tellurium reaches $4 \%$ in metasomatically altered rocks, while bismuth shows $0.9 \%$.

Main Manifestations of Bismuth-Tellurium Mineralization in Metasomatically

Table 1 Altered Neovolcanites of the Vyghorlat-Ghuta Ridge

\begin{tabular}{|c|c|c|}
\hline $\begin{array}{c}\text { Bi Mineralization } \\
\text { Distribution Locality }\end{array}$ & Bi Mineralization Metasomatites & Bismuth Abundant Minerals \\
\hline Podulky & $\begin{array}{c}\text { kaoline-hydromica and } \\
\text { quartz-turmaline-topaz-mica metasomatites }\end{array}$ & tsumoite, Ag-tsumoite, pilsenite \\
\hline Il'kovtsy & kaolinite-hydromica-smectite metasomatites & pilsenite, tsumoite, native bismuth, $\mathrm{Bi}_{2} \mathrm{Te}$ phase \\
\hline Smerekiv Kamin & $\begin{array}{l}\text { hydromica-smectite metasomatites with lenses } \\
\text { of secondary quartzites }\end{array}$ & $\begin{array}{l}\text { bismutite, tsumoite, Te-sulfonevskite, zhozeite, } \\
\text { pilsenite, } \mathrm{Bi}_{3} \mathrm{Te}_{1,5} \mathrm{~S}_{0,5} \text { and } \mathrm{Bi}_{2} \mathrm{Te}_{0,5} \mathrm{~S}_{0,5} \text { phases }\end{array}$ \\
\hline $\begin{array}{l}\text { Poruba pod Vyhorlatom, } \\
\text { Remetske Hamre }\end{array}$ & $\begin{array}{l}\text { kaolinite-hydromica metasomatites with lenses } \\
\text { of secondary quartzites }\end{array}$ & $\begin{array}{l}\text { telluronevskite }\left(\mathrm{Bi}_{3} \mathrm{TeSe}_{2}\right) \text {, vyghorlatite }\left(\mathrm{Bi}_{8+x}\right. \\
\left.(\mathrm{Se}, \mathrm{Te}, \mathrm{S})_{11-\mathrm{x}}\right)\end{array}$ \\
\hline
\end{tabular}

Bismuth mineralogy of the Vyhorlat-Ghuta ridge. The main bismuth-bearing associations of the Vyhorlat-Ghuta ridge are mostly represented by tellurides, sulfotellurides, native bismuth and local bismuth sulphides, and oxides [5].

Bismuth tellurides. Bismuth telluride, first found in 1950s-60s in the delluvial-alluvial sediments and further in solid rocks in the vicinity of Perechyn, Ilkovtsy, Podulky villages and Syniak resort, was initially defined as "wehrlite" [1]. Later, after x-ray research of "wehrlite" monocrystal plates was carried out, "wehrlite" was noticed to have heterogeneous structure [8]; thus, it was defined that "wehrlite" consists of several mineral phases which form a structure of epytaxial intergrowths in a plane (0001). The findings facilitated identifying such mineral phases as tsumoite - BiTe, pilsenite $-\mathrm{Bi}_{4} \mathrm{Te}_{3}$, and $\mathrm{Bi}_{2} \mathrm{Te}$ phase [9] in the chemistry of "primary wehrlite".
The investigations of natural Bi-tellurides of the transCarpathian region and Slovakia have shown that they are characterised by considerable variations of $\mathrm{Bi} / \mathrm{Te}$ ratio. When calculating their crystallochemical formulae, it is often impossible to reach stoichiometric ratios between atoms of metals - (bismuth) and $(\mathrm{Te}+\mathrm{Se}+\mathrm{S})$. More often these proportions are of 2:2, 2:3; 3:2, 4:3 and 8:5. According to the X-ray-structural investigations of tellurides their non-stoichiometry results from a mixed-layered structure identified in tsumoite, pilsenite and at a phase which chemistry is similar to $\mathrm{Bi}_{2} \mathrm{Te}$.

Among Bi-rich ore minerals, there were established such varieties as tsumoite $(\mathrm{BiTe})$, pilsenite $\left(\mathrm{Bi}_{4} \mathrm{Te}_{3}\right)$, zhozeit $\left(\mathrm{Bi}_{4} \mathrm{Te}_{2} \mathrm{~S}\right)$, vyghorlatite $\left(\mathrm{Bi}_{8+\mathrm{x}}(\mathrm{Se}, \mathrm{Te}, \mathrm{S})\right.$ 11-x $)$ and telluronevskite $\left(\mathrm{Bi}_{3} \mathrm{TeSe}_{2}\right)$. Some other mineral phases (Table $1)$, referred to in the publications [10], remain insufficiently 
investigated for the computational complexity of obtaining reliable x-ray data, the existence of natural solid solutions and sporadic occurrences of isomorphic replacements. It is also worth mentioning that there is identified a considerable increase of selenium content within the area of the Vyhorlat-Ghuta ridge stretching on the territory of Slovakia.

Native bismuth is widespread in montmorillonite metasomatites within Smerekiv Kamin area. Here it forms spheroidal segregations overgrowned by joseite and impregnated with tellurides.

Beyond tellurides, sulphides (ikunolite, $\mathrm{Bi}_{4} \mathrm{~S}_{3}$ ) and native bismuth there were identified secondary oxides (currently insufficiently studied) that, being film-like in form, spread along the tellurides in the metasomatites of llkovtsy manifestation

The X-ray-structural analysis indicates the film to be composed of smirnit $\left(\mathrm{Bi}_{2} \mathrm{Te}_{5}\right)$ or a mixture of smirnit and $\mathrm{Bi}_{2} \mathrm{Te}_{2} \mathrm{O}_{7}$ oxide. These oxides form only from pilsenite and a mineral whose chemistry is similar to $\mathrm{Bi}_{2} \mathrm{Te}$. In the Poruba pod Vyhorlatom mineralised area secondary bismuth minerals are mainly represented by montanite.

Conclusions. Mineralogical and geochemical research being carried out, the following features of bismuth behaviour in the Neogene volcanites of the Ukrainian Carpathians and Slovakia can be distinguished:

1. The Miocene epithermal deposits are characterised by native gold-bismutite-chalcopyrite-quartz evolving from neutral solutions that persist adularia due to the replacement of the earlier formed sulphides, mostly galenite. The decrease of $\mathrm{Ag} / \mathrm{Cu}$ ratio in time is indicative of this stage. A considerable number of mineral phases might be explained by their mostly being metastable and intermediate links which are formed during metasomatic replacements caused by spatial and time variations in hydrothermal solution parameters.

2. In the metasomatically altered Pliocene volcanites of the Vyhorlat-Ghuta ridge there is abundant bismuthtellurium-selenic mineralization. Bismuth-tellurium ore manifestations are associated with high-temperature pneumatolytic-hydrothermal systems, in which acid solu- tions are predominant, which is proved by a wide distribution of kaolinite-hydromica metasomatites. According to the rates of $\mathrm{Bi}-\mathrm{Te}-\mathrm{Se}$ mineralization, the Vyhorlat-Ghuta ridge is likely to become a unique province on the European continent, in metallogenic and mineralogical sense.

References

1. Biruk S., Skakun L., (2000). Bismuth Minerals of the Beregovo Ore Field: Mineral Assemblages and Spatial Zonation (Transcarpathian, Ukraine). Geological Quarterly, 44, 1, 39-46.

2. Ciobanu C.L., Pring A., Cook N.J., Self P. et al., (2009). Chemicalstructural Modularity in the Tetradymite Group: A HRTEM Study. Amer. Mineral., 94, 4, 517-534.

3. Jeleň S., Ponomarenko O., Mikuš T., Skakun L. et al., (2012). The Occurrence and Distribution Features of Bismuth in Neogene Volcanites of Slovakian and Ukrainian Carpathians. Acta Mineralogica-Petrographica, Joint 5th Mineral Sciences in the Carpathians Conference and 3rd CentralEuropean Mineralogical Conference 20-21 April, 2012, University of Miskolc, Miskolc, Hungary, Abstract Series, Szeged, 7, 67.

4. Jelen S., Mikus T., Prsek J., (2009). Sulphosalts of Cuprobismutite Homologous Series from Banska Hodrusa and Cierna Lehota (Western Carpathians, Slovakia). Mineralogichnyi zbirnyk. Lviv, 59, 2, 64-76.

5. Kovalenker V.A., Jelen S., Sandomirskaya S., (1993). Minerals of the System Ag-Cu-Pb-Bi-S from the Polymetallic Viens of the Stiavnica-Hodrusa Ore Field (Slovakia). Geologica Carpathica, 44, 6, 409-423.

6. Коптюх Ю.М., (1992). Золото-полиметаллическое оруденение Внутрикарпатского вулканического пояса. Киев: Наукова думка, 146.

Koptyukh Yu.M., (1992). Gold-base Metal Mineralization of the InnnerKarpathian Volcanic Belt. Kiev: Naukova dumka, 146 (in Russian)

7. Лазаренко Е.К., Лазаренко Э.А., Барышников Э.К., Малыгина О.А., (1963). Минералогия Закарпатья. Львов: Изд-во Львов. ун-та, 614 с.

Lazarenko E.K., Lazarenko E.A., Baryshnikov E.K., Malygina O.A., (1963). Mineralogy of Transcarpathians. Lvov: Publishing House of Lvov. Un-sity, 614 p. (in Russian)

8. Melnikov V., Jeleň S., Bondarenko S., Bálintová T. et al., (2010). Comparative Study of Bi-Te-Se-S Mineralizations in Slovak Republic and Transcarpathian Region of Ukraine. Part 2. Crystal Chemistry and Genesis of Layered Bi-tellurides. Mineralogichnyi zhurnal. - Mineralogical Journal, $32,1,38-44$.

9. Seghedi I., Downes H., (2011). Geochemistry and Tectonic Development of Cenozoic Magmatism in the Carpathian Pannonian Region. Gondwana Research, 20, 4, 655-672.

10. Sejkora J., Litochleb J., Černý P., Ozdín D., (2004). Bi-Te Mineral Association from Župkov (Vtáčnik Mts., Slovak Republic). Mineralia Slovaca, 36, 3-4, 303-315.

11. Ztevkova T., (2012). Kryitalochimia Mineralov Tetradymitovej Skupiny a Stadium Bi-Se-Te Mineralizacie na Vybranych Lokalitach Zapadnych Karpat a Vihorlatu. Dizertačná práca: PhD in Petrology. Bratislava, 163 p. (in Slovak). Надійшла до редколегї̈ 15.09.14

\author{
С. Єлень, канд. наук, наук. ст. наук. співроб. \\ E-mail: jelen@savbb.sk \\ Геологічний інститут, Словацька Академія наук \\ вул. Думберська 1., м. Банська Бистриця, Словаччина, 97401 \\ л. Скакун, канд. геол.-мін. наук, доц. \\ E-mail: Izskakun@gmail.com \\ Львівський національний університет ім. Івана Франка \\ вул. Грушевського 4, м. Львів, Україна, 79005 \\ О. Грінченко, канд. геол.-мінералог. наук, доц. \\ E-mail: alexgrin@univ.kiev.ua \\ Київський національний університет іменіТараса Шевченка \\ ННІ "Інститут геології", вул. Васильківська, 90, м. Київ, 03022, Україна \\ С. Бондаренко, канд. геол. наук, ст. наук. співроб. \\ E-mail: sbond@igmof.gov.ua \\ Інститут геохімії, мінералогії та рудоутворення Національної Академії наук України \\ пр. Паладіна, 34, м. Київ-142, Україна, 03680 \\ Т. Мікуш, канд. наук, наук. співроб. \\ E-mail: mikus@savbb.sk \\ Геологічний інститут, Словацька Академія наук \\ вул. Думберська 1., м. Банська Бистриця, Словаччина, 97401 \\ Т. Штевкова, канд. наук, наук співр. \\ E-mail: timea.stevkova@apvv.sk \\ Університет ім. Яна Коменськего \\ Факультет прирородничих наук, вул. Млинська долина В-1, М. Братислава, Словаччина, 84215 \\ Т. Мірончук, канд. фрілол. наук, доц. \\ E-mail: tatianakiev99@gmail.com, \\ Київський національний університет імені Тараса Шевченка \\ НHI "Інститут геології", вул. Васильківська, 90, м. Київ, 03022, Україна
}

\title{
МІНЕРАЛІЗАЦІЯ ВІСМУТУ В НЕОГЕНОВИХ ВУЛКАНІТАХ УКРАЇНСЬКИХ КАРПАТ І СЛОВАЧЧИНИ
}

У статmі викладено матеріал щодо особливостей поширення вісмутової мінералізації у неогенових вулканітах України та Словаччини. Вісмут є типовим елементом багатьох золоторудних, поліметалічних і міднопорфирових неогенових родовищ Українського Закарпаття та Словаччини. Завдяки своїй здатності до мінералоутворення, вісмут характеризується можливістю формування значної кількості мінеральних різновидів, які є чутливими до певних фізико-хімічних умов середовища. В зв'язку з цим вивчення особливостей поведінки вісмуту має важливе значення для дослідження особливостей та характеристики процесу рудогенезу. Незважаючи на 
той факт, що в більшості випадків мінерали вісмуту формують субмікроскопічні виділення, вони можуть слугувати індикаторами фізико-хімічних умов формування рудних систем, тому що їх склад є високочутливим до незначних змін таких параметрів як темпеpamypa, $\mathrm{Eh}-\mathrm{pH}, \mathrm{fTe} \mathrm{e}_{2}, \mathrm{fS}_{2}, \mathrm{fSe}_{2}, \mathrm{fO}_{2}$ та iнui.

Як у межах Закарпатського регіону України так і на території Словаччини контрастно простежуються два етапи вісмутового мінералоутворення, які синхронізуються відповідно з проявами вулканізму міоценового та пліоценового віку. Кожний етап прояву вулканічної діяльності характеризується певним типоморфним набором вісмутових мінералів та різним ступенем інтенсивності прояву власне вісмутової мінералізації. Було встановлено, що сульфосолі вісмуту є характерними для міоценових вулканітів та асоційованих з ними епітермальних родовищ, в той час як прояви вісмут-телурової мінералізації є широко розповсюдженими в метасоматично змінених вулканітах пліоценового віку.

Міоценові епітермальні родовища характеризуються парагенезисом самородне золото-Ві-сульфосолі-вісмутин-халькопіритквари, що формується із нейтральних розчинів (постійна присутність адуляру) внаслідок зміщення раніше утворених сульфідів, пери за все галеніту. Характерним для цього етапу є зменшення співвідношення Ag/Cи в часі. Велика кількість мінеральних фаз пояснюється тим, що більшість із них є метастабільним, проміжними ланками, що утворюються при процесах метасоматичних заміщень на фоні просторових та часових варіацій параметрів гідротермальних розчинів.

У метасоматично змінених пліоценових вулканітах Вигорлат-Гутинського пасма поширена вісмут-телур-селенова мінералізація. Вісмут-телурові рудопрояви повязані з високотемпературними пневматоліто-гідротермальними системами, в яких переважали кислі розчини, що підтверджується широким поширенням каолініт-гідрослюдистих метасоматитів. Масштаби прояву процесів Ві-Те-Sе мінералізації у пліоценових вулканітах Вигорлат-Гутинського пасма дають можливість розглядатися цю структуру як унікальну металогенічну провінцію Європейського континенту.

Ключові слова: вісмут, мінералізація, Україна, Словаччина.

С. Елень, канд. наук, ст. науч. сотр.,

E-mail: jelen@savbb.sk

Геологический институт, Словацкая Академия наук

ул. Думберская 1., г. Банская Быстрица, Словакия, 97401,

Л. Скакун, канд. геол.-мин. наук, доц.,

E-mail: Izskakun@gmail.com

Лвовский национальный университет имени Ивана Франко

Геологический факультет, ул. Грушевского 4, г. Львов, Украина, 79005,

А. Гринченко, канд. геол.-мин. наук, доц.,

E-mail: alexgrin@univ.kiev.ua

Киевский национальный университет имени Тараса Шевченко

УнИ "Институт геологии", ул. Васильковская, 90, г. Киев, 03022, Украина

С. Бондаренко, канд. геол. наук, ст. науч. сотр.,

E-mail: sbond@igmof.gov.ua

Институт геохимии, минералогии и рудообразования Национальной Академии наук Украины

пр. Палладина, 34, г. Киев-142, Украина, 03680

Т. Микуш, канд. наук, науч. сотр.,

E-mail: mikus@savbb.sk

Геологический институт, Словацкая Академия наук

ул. Думберская 1., г. Банская Быстрица, Словакия, 97401

Т. Штевкова, канд. наук, науч. сотр.,

E-mail: timea.stevkova@apvv.sk

Университет им. Яна Каменского

Факультет естественных наук, ул..Млынська долина В-1, г. Братислава, Словакия, 84215,

Т. Мирончук, канд. филол. наук, доц.,

E-mail: tatianakiev99@gmail.com

Киевский национальный университет имени Тараса Шевченко

УнИ "Институт геологии", ул. Васильковская, 90, г. Киев, 03022, Украина

\section{МИНЕРАЛИЗАЦИЯ ВИСМУТА В НЕОГЕНОВЫХ ВУЛКАНИТАХ УКРАИНСКИХ КАРПАТ И СЛОВАКИИ}

В статье изложен материал относительно особенностей распространения висмутовой минерализации в неогеновых вулканитах Украины и Словакии. Висмут является типичным элементом многих золоторудных, полиметаллических и меднопорфировых неогеновых месторождений украинского Закарпатья и Словакии. Благодаря своей способности к минералообразованию висмут характеризуется возможностью формирования значительного количества минеральных разновидностей, которые являются чувствительными к определенным физико-химическим условиям среды. В связи с этим изучение особенностей поведения висмута имеет важное значение для исследования особенностей и характеристики процесса рудогенеза. Несмотря на тот факт, что в большинстве случаев минералы висмута формируют субмикроскопичные агрегаты, они могут служить в качестве индикаторов физикохимических условий формирования рудных систем, потому что их состав является высокочувствительным к незначительным изменениям таких параметров как температура, Eh-PH, fTe $\mathrm{fS}_{2}, \mathrm{fSe}_{2}, \mathrm{fO}_{2}$ u другuе.

Как в пределах Закарпатского региона Украины так и на территории Словакии контрастно прослеживаются два этапа висмутового минералообразования, которые синхронизируются соответственно с проявлениями вулканизма миоценового и плиоценового возраста. Каждый этап проявления вулканической деятельности характеризуется определенным типоморфным набором висмутовых минералов и разной степенью интенсивности проявления самой висмутовой минерализации. Установлено, что сульфосоли висмута характерны для миоценовых вулканитов и ассоциированных с ними эпитермальных месторождений, в то время как проявления висмут-теллуровой минерализации широко распространены в метасоматически измененных вулканитах плиоценового возраста.

Миоценовые эпитермальные месторождения характеризуются парагенезисом самородное золото Ві-сульфосоли-висмутинхалькопирит-кварц, который формируется из нейтральных растворов (постоянное присутствие адуляра) вследствие замещения ранее образованных сульфидов, прежде всего галенита. Характерным для этого этапа является уменьшения соотношения Аg/Си во времени. Большое количество минеральных фаз объясняется тем, что большинство из них являются метастабильным, промежуточными звеньями, которые образовываются при процессах метасоматических замещений на фоне пространственных и временных вариаций параметров гидротермальных растворов.

В метасоматически измененных плиоценовых вулканитах Выгорлат-Гутинской гряды распространена висмут-теллур-селеновая минерализация. Висмут-теллуровые рудопроявления связаны с высокотемпературными пневматолито-гидротермальными системами, в которых преобладали кислые растворы, что подтверждается широким распространением каолинит-гидрослюдистых метасоматитов. Маситабы проявления процессов Bi-Te-Se минерализации в плиоценових вулканитах Выгорлат-Гутинской гряды дают возможность рассматривать данную структуру как уникальную металлогеническую провинцию Европейского континента.

Ключевые слова: висмут, минерализация, Украина, Словакия. 